DOI: 10.22591/magyurol.2017.4.javorhazya.149

\title{
Új biomarkerek a konvencionális veserák progressziójának megitélésére
}

\author{
Jávorházy András dr., Farkas László dr., Szántó Árpád dr., Kovács Gyula dr.
} Pécsi Tudományegyetem, Urológiai Klinika, Pécs (igazgató: Szántó Árpád dr.)

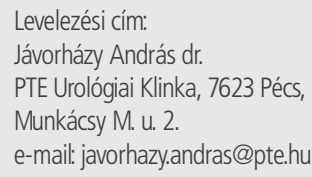

\section{ÖSSZEFOGLALÁS \\ Célkitüzés: A modern képalkotó eljárások széles körű al- kalmazásának köszönhetően a konvencionális veserák (CRCC) egyre nagyobb arányban kerül korai stádiumban felismerésre, ennek ellenére a szervre lokalizált állapotban diagnosztizált be- tegek 10-15\%-a továbbra is a betegség progressziója követ- keztében halálozik el. Vizsgálatunk célja új biomarkerek azo- nositása, amelyek alkalmasak a posztoperatív progresszió elő- rejelzésére.}

Módszerek: Az előzetes géntérképezés (Affymetrix array) során potencionális biomarkerként azonosított szérum amyloid A1 (SAA1), mátrix metalloproteináz 12 (MMP12) és transzmembrán protein 27 (TMEM27) fehérjék kifejeződését vizsgáltuk immunhisztokémiai módszerrel cRCC miatt operált betegek szövetmintáiból készített "tissue-chip" (tissue multi array, TMA) felhasználásával. Egy és többváltozós Cox-regressziós modell segítségével elemeztük a daganatspecifikus túlélés és a fenti fehérjék expressziója közötti összefüggést. A változók túlélési időre gyakorolt hatását Kaplan-Meier-analízis segítségével mértük fel, a túlélési görbék összehasonlítását log-rank teszt alkalmazásával végeztük.

Eredmények: A Kaplan-Meier túlélési analízis kedvezőtlen daganatspecifikus túlélést jelzett az SAA1-, valamint az MMP12-antitesttel festődő tumoroknál. A TMEM27-festődés hiánya szintén rossz daganatspecifikus túléléssel társul. A Coxregressziós modell alkalmazása során szignifikáns összefüggés volt látható a túlélés és az SAA1, MMP12 és TMEM27expresszió között. Mindhárom biomarker független prognosztikai faktornak bizonyult a felismeréskor szervre lokalizált eseteket tartalmazó betegcsoportokat vizsgálva.

Következtetés: Eredményeink alapján szervre lokalizált cRCC esetén az SAA1, MMP12 és TMEM 27 immunhisztokémia ígéretes módszer a posztoperatív progresszió szempontjából magas rizikóval bíró betegek azonosítására.

\section{KULCSSZAVAK}

VESESETES RÁK, IMMONHISZTOKÉMIA, TUMORPROGRESSZIÓ, SAA1, MMP12, TMEM27

\section{New biomarkers to predict the prog- nostic pattern of patients with conven- tional renal cell carcinoma}

\section{SUMMARY}

Purpose: In spite of early detection of conventional renal cell carcinoma (RCC) by widespread use of abdominal imaging approximately $10-15 \%$ of patients will die due to disease. The aim of this study was to identify new biomarkers predicting the postoperative progression of conventional RCC.

Methods: Tissue multi arrays (TMA) of conventional RCC patients were analysed by immunohistochemistry for expression of the acute phase protein serum amyloid A1 (SAA1), the matrix metalloproteinase 12 (MMP12) and the transmembrane protein 27 (TMEM27) which were identified as candidate biomarkers formerly by global gene expression analysis (Affymetrix array). Univariate and multivariate Cox-regression models were addressed to assess cancer specific survival in association of protein expression. Cancer specific survival time was estimated with Kaplan-Meier analysis, the comparison of survival curves was made with the Log rank test.

Results: The Kaplan-Meier survival analysis indicated a poor disease specific survival rates for tumours with SAA1 and MMP12 staining. The lack of TMEM27 staining was also associated with poor disease specific survival rates. Cox-regression analysis revealed significant association of patient survival with SAA1, MMP12 and TMEM27 expression. All the three biomarkers proved to be independent prognostic factors in the cohort of patients without metastatic disease at the time of operation

Conclusions: Our results suggest that SAA1, MMP12 and TMEM27 immunochemistry in localised conventional RCC is a promising method to define a group of patients at high risk for postoperative progression.

\section{KEYVWORDS}

RENAL CELL CARCINOMA, IMMUNOCHEMISTRY, TUMOUR PROGRESSION, SAA1, MMP12, TMEM27 


\section{Bevezetés}

A renocelluláris karcinóma (RCC) az összes daganatos megbetegedés 2-3 százalékát teszi ki, incidenciája a nyugati országokban magasabb. Európában 2012 folyamán 84000 új esetet diagnosztizáltak, metasztatikus betegség következtében 35000 haláleset fordult elő (1). A veserák típusai közül leggyakoribb az összes vesedaganat mintegy 75 százalékát kitevő, magas mortalitású konvencionális típusú RCC. Az ide sorolható betegek körülbelül harmadánál észlelhető metasztázis már felismeréskor, vagy a nyomonkövetés során. A veserák elsődleges kezelési módja továbbra is a radikális vagy parciális nephrectomia. Teljes gyógyulást csak a szervre lokalizált esetekben, idóben elvégzett mútéti kezelés eredményezhet. A közelmúltban bevezetett, metasztatikus esetekben alkalmazható tirozin-kináz-gátló kezeléssel a túlélési idő növelhető, azonban komplett remisszió már nem érhető el. A modern képalkotó eljárások széles körü alkalmazásának köszönhetően a korai stádiumban felismert, kisméretú daganatok aránya növekszik. A korai diagnózis ellenére a szervre lokalizált, kuratív szándékkal operált esetek mintegy 15 százalékánál jelentkezik metasztázis 5 éven belül. Emiatt nagy igény mutatkozik olyan biomarkerek iránt, amelyek alkalmasak a posztoperatív progresszió szempontjából magas rizikójú esetek azonosítására. A veserák kimenetelével összefüggésbe hozható biomarkerek használhatóak a progresszió előrejelzésére önállóan vagy más molekuláris és klinikai faktorokkal együtt integrált prognosztikai rendszerekbe ágyazva (2-5).

Vizsgálatunk célja olyan új biomarkerek azonosítása, amelyek alkalmasak a szervre lokalizált konvencionális veserák posztoperatív prognózisának elórejelzésére. A rosszindulatú tumorok progressziója a daganat és mikrokörnyezet közti kapcsolat megváltozásával és a tumorsejtek dedifferenciálódásával függ össze. Ezen tényezők vizsgálatára három gént választottunk ki:

- A: A tumor stromában lezajó gyulladásos folyamatoknak fontos szerepe van a progresszióban (6). Ennek vizsgálatára kiválasztottunk egy akut fázis fehérjét, az SAA1-t kódoló gént.

- B: A környező stroma átalakítása, lebontása egyik előfeltétele a tumorsejtek mozgásának $(7,8)$. Ennek vizsgálatára a szarkomatoid veserákokban kifejeződő metalloproteináz 12 (MMP12) kifejeződését vizsgáltuk konvencionális veserákban.

- C: A progresszió során a legtöbb daganat elveszíti polarizált hám jellegét és sok esetben polarizálatlan szarkomatoid formát vesz fel.

A daganatsejtek mozgásához szükség van erre az átalakulásra (9). Ennek a sejtváltozásnak a vizsgálatára a TMEM27-gén kifejeződését néztük meg, amely kizárólag a proximális tubulusban mint strukturális fehérje található meg.

A dolgozatban tárgyalt biomarkerek kiválasztása a progrediáló és nem progrediáló konvencionális, valamint a szarkomatoid jelleget mutató veserákmintákon előzetesen elvégzett globális génexpresszió-analízis (Affymetrix) és az azt követő reverz transzkripciós PCR eredményeinek figyelembe vételével történt meg. Ezen vizsgálatok a Heidelbergi Ruprecht-Karls-Egyetemen prof. Kovács Gyula vezetésével múködő Molekuláris Onkológiai Laboratóriumban és a szintén Heidelbergben múködő European Molecular Biology Laboratory genomikai részlegén zajlottak.

\section{Betegek és módszerek}

A Pécsi Tudományegyetem Urológiai Klinikán 2000. január és 2010. december közÖtt konvencionális veserák miatt radikális vagy parciális nephrectomián átesett betegek közül a jó nyomonkövetési adatokkal rendelkező esetek retrospektív módon kerültek beválasztásra.

A nyomonkövetési és halálozási adatokat a PTE Urológiai Klinika dokumentációs rendszereiből (Betegregiszter, Intramed, eMedSol) nyertük. Nyomonkövetési időnek a mútéttől az utolsó dokumentált kontrollvizsgálatig vagy a beteg veserák következtében bekövetkezett haláláig eltelt időt tekintettük. A vesetumortól független okból kifolyólag elhunyt betegeket a nyomonkövetési idő kiszámításánál nem vettük figyelembe. Staging céljából a mútét előtt minden esetben mellkasröntgen, has és kismedencei $\subset$-vizsgálat történt. Agyivagy csontmetasztázis jelenlétére utaló klinikai tünetek fennállása esetén csontszcintigráfia és koponya $\subset$-vizsgálatot is végeztettünk. Nyirokcsomó-érintettség megállapításánál a szövettani eredményt, távoli áttéteknél a képalkotó vizsgálatok eredményeit vettük alapul. A mútétet követő nyomonkövetés során hathavonta végeztünk hasi ultrahangvizsgálatot, mellkasröntgent és laborvizsgálatot, évente hasi és kismedence $C T$-vizsgálatot. A szövettani diagnózis minden esetben uropatológus (K.Gy.) által felülvizsgálatra került a heidelbergi klasszifikációs rendszernek megfelelően (10). A TNM-stádium megállapítását a 2009-es TNM-klasszifikáció szerint végeztük (11). A nukleáris grádus meghatározása háromfokozatú rendszer alkalmazásával történt. A szövetminták gyüjtését és feldolgozását a PTE ÁOK Etikai Bizottság engedélyének birtokában végeztük (Etikai engedély száma: 5343/2014).

\section{Tissue microarray}

A vizsgálat során fötális és felnőtt egészséges veseszövetet, valamint konvencionális és más típusú renocelluláris karcinómát tartalmazó paraffin blokkokat használtunk fel tissue microarray (TMA) készítéséhez. A tumoros blokkokból készített hematoxilin-eozin festett metszetek áttekintése során került kijelölésre a mintavétel helye. Ezt követően a kijelölt területnek megfelelően a paraffinba ágyazott szövetblokkból Manual Tissue Arrayer (MTA1, Beecher Instruments, Inc., Sun Prairie, USA) készülék segítségével 0,6 mm átmérőjú szövethengereket emeltünk ki. Különböző morfológiájú vagy grádusú területekkel rendelkező tumorokból több (2-4) mintát vettünk. Az így nyert szövethengereket az MTA1-készülék segítségével egy közös paraffin blokkba ágyaztuk be, lehetővé téve 100-150 különböző minta egy metszeten történő egyidejú vizsgálatát. Az antitest-festődés ellenőrzése céljából a TMA készítésekor egészséges fötális és felnőtt vese mintákat is beépítettünk.

\section{Immunhisztokémia}

A TMA-kból készített 4 um vastagságú metszetekből a paraffint xilol segítségével eltávolítottuk, majd a metszeteket leszálló 


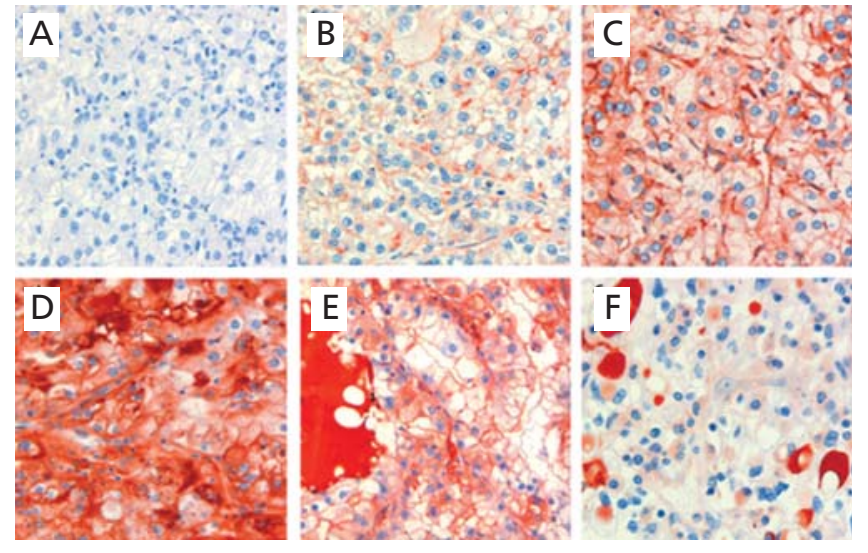

1. ÁBra: Példák SAA1-Antitesttel VÉGZett ImMunnhISZTOKÉMIA SORÁN ÉSZLELT KÜLÖNBÖZŐ MÉRTÉKŰ FESTŐDÉSRE: SAA1-FESTŐDÉS HIÁNYA (A), GYENGE SEJTMEMBRÁN FESTŐDÉS (B), ERÖS MEMBRÁN (C) ÉS CITOPLAZMATIKUS (D) TUMORSEJT FESTŐDÉS, SAA1 POZITÍV FOLYADÉK TARTALMÚ CISZTA (E), VALAMINT ERŐSEN FESTŐDŐ, NAGYMÉRETỦ INTRACITOPLAZMATIKUS ZÁRVÁNYOK (E) 400-SZOROS NAGYÍTÁS MELLETT

etanol sorozatban rehidráltuk. Ezt követően az antigén feltárás az SAA1, MMP12 és TMEM27 esetén $10 \mathrm{mM}$ nátrium-citrát pufferben (pH 6,0), a HNF1A esetén TE pufferben $(\mathrm{pH} 9,0)$ történő forralással értük el, amit a 2100-Retriever (Pick-Cell Laboratories, Amsterdam, Hollandia) készülékben végeztünk el. Az endogén peroxidáz-aktivitás és a nem specifikus kötőhelyek blokkolása $1 \%$ normál lószérumot tartalmazó $0,3 \%$-os hidrogén-peroxidban történt szobahőmérsékleten 10 percig. Ezt követően a metszeteket éjszakán át nedves kamrában $4{ }^{\circ} \mathrm{C}$-on inkubáltuk. A következő antitesteket használtuk fel: nyúl anti-SAA1 antitest (ab655, Abcam, Cambridge, UK), 1:100 hígításban; nyúl anti-TMEM27-antitest (ab200664, Abcam, Cambridge, UK), 1:1000 hígításban; nyúl anti-HNF1A antitest (PA5-22310, Thermo Fisher Scientific, Budapest, Hungary), 1:500 higításban; nyúl anti-MMP12 antitest (NBP1-31225, Novus Biologicals, Littleton, CO, USA), 1:250 hígításban. Harminc percig történő HRP konjugált anti-nyúl másodlagos antitest (MACH4 Universal HRP-Polymer, Biocare Medical, Concord, USA) alkalmazását követően az előhívás AEC szubsztrát és DAB (DAKO) segítségével történt, majd a metszeteket Mayer hematoxillinnel festettük. Végül a metszetek kétszeres kiértékelése történt a klinikai adatok ismerete nélkül.

\section{Statisztikai analízis}

Az adatok statisztikai feldolgozása az SPSS Statistics szoftver 23.0 verzió (IBM, 35 Armonk, NY, USA) segítségével történt. A vizsgált gének expressziója és a klinikopatológiai paraméterek közti összefüggéseket a khi-négyzet próba alkalmazásával elemeztük. A különböző változók (életkor, nem, tumorméret, TNM-klasszifikáció, nukleáris grádus, stádium, metasztázis jelenléte és a vizsgált gén expressziója) túlélési időre gyakorolt hatását Kaplan-Meier-analízis segítségével mértük fel, a túlélési görbék összehasonlítását log-rank teszt alkalmazásával végeztük. A túlélésre gyakorolt hatás egyváltozós és többváltozós analízise a Cox-regressziós modell segítségével történt. A vizsgálat lezárultakor életben lévő és tumormentes betegeket cenzoráltuk. A különbséget 0,05-nél kisebb p-érték esetén tekintettük szignifikánsnak.

\section{Eredmények}

\section{Az SAA1-expresszió immunhisztokémiai vizsgálata}

Az SAA1-expresszió vizsgálatát 429 betegnél végeztük el. Felismeréskor valamennyi esetben a betegség szervre lokalizált volt. Az átlagos nyomonkövetési idő $73,53 \pm 4,6$ hónap volt. A nyomonkövetés során 78 betegnél (18\%) alakult ki progresszió. A férfinő arány 266:163 (62\% és 38\%), az átlagos életkor $61,4 \pm 11,2$ év volt. Az átlagos tumorméret $50,1 \pm 25,5 \mathrm{~mm}$ volt. Az immunhisztokémiai vizsgálat során fötális és felnőtt normál veseszöveten SAA1-festődés nem volt észlelhető. Az veserákminták nagy többsége szintén SAA1 negatívnak bizonyult. A 429 tumoros minta közül csupán 20 mutatott különböző intenzitású SAA1-festődést. A pozitív esetekben az SAA1-fehérje időnként kisméretű csomókat formálva a sejtfalban halmozódott, azonban az intenzívebb reakciót mutató esetekben citoplazmatikus festődés is előfordult. A szolid tumorszövetben megfigyelhetőek voltak kisméretú, tumorsejtekkel szegélyezett ciszták, melyek SAA1 pozitív folyadékot tartalmaztak. Néhány esetben gyenge citoplazmatikus festődés mellett nagyméretú SAA1 pozitív intracitoplazmatikus zárványok alakultak ki (1. ábra).

\section{Az SAA1-expresszió összehasonlítása a kli- nikopatológiai jellemzőkkel}

Az SAA1-expresszió és a klinikopatológiai változók, mint a daganatspecifikus halálozás, a tumorméret, a nukleáris grádus és a T-stádium közötti viszony statisztikai elemzése során mindegyik paraméter tekintetében szignifikáns összefüggés volt kimutatható $(p<0,001)$ (1. táblázat).

\section{Az SAA-expresszió és a túlélési adatok kö- zötti összefüggés}

A log-rank teszt alkalmazásával végzett Kaplan-Meier túlélésanalízis az SAA1-antitesttel pozitívan festődő tumorok esetén lényegesen rövidebb daganatspecifikus túlélést igazolt (2. ábra). A medián túlélési idó az SAA1 pozitív betegeknél 58 hónap (33-82, 95\% Cl) volt. Egyváltozós analízis (2. táblázat) alapján az SAA1 pozitív tumorral rendelkező betegeknél a daganatspecifikus halálozás kockázata szignifikánsan magasabb (RR: 6,61; 95\% Cl: -3,70-11,83). Az SAA1-festődés független prognosztikai értékének meghatározása érdekében többváltozós analízist is végeztünk az ismert klinikopatológiai prognosztikai változókat figyelembe véve. Többváltozós analízis során az SAA1-expresszió - a T-stádium és a nukleáris grádus mellett - független prognosztikai faktornak bizonyult (RR: $-2,11 ; 95 \% \mathrm{Cl}:-1,14-3,92 ; \mathrm{p}=0,017)$. 
1. TÁBLÁZAT: AZ SAA1-EXPRESSZIÓ ÉS A KONVENCIONÁLIS VESERÁK KLINIKOPATOLÓGIAI JELLEMZŐI KÖZÖTTI ÖSZSZEFÜGGÉSEK

\begin{tabular}{|c|c|c|c|c|}
\hline & \multirow{2}{*}{$\begin{array}{l}\text { Esetek } \\
\text { száma } \\
\text { (429) }\end{array}$} & \multicolumn{2}{|c|}{ SAA1 } & \multirow{2}{*}{ p-érték } \\
\hline & & + & - & \\
\hline $\begin{array}{l}\text { Státusz } \\
\text { AWOD } \\
\text { DOD }\end{array}$ & $\begin{array}{c}351 \\
78\end{array}$ & $\begin{array}{r}6 \\
14\end{array}$ & $\begin{array}{r}345 \\
64\end{array}$ & $p<0,001$ \\
\hline $\begin{array}{l}\text { Tumorméret } \\
<4 \mathrm{~cm} \\
4-7 \mathrm{~cm} \\
>7 \mathrm{~cm}\end{array}$ & $\begin{array}{r}192 \\
153 \\
84\end{array}$ & $\begin{array}{r}2 \\
5 \\
13\end{array}$ & $\begin{array}{r}190 \\
148 \\
71\end{array}$ & $p<0,001$ \\
\hline $\begin{array}{l}\text { Grade } \\
\text { G1 } \\
\text { G2 } \\
\text { G3 }\end{array}$ & $\begin{array}{r}278 \\
116 \\
35\end{array}$ & $\begin{array}{r}2 \\
10 \\
8\end{array}$ & $\begin{array}{r}276 \\
106 \\
27\end{array}$ & $p<0,001$ \\
\hline $\begin{array}{l}\text { T-stádium } \\
\text { 1a-b } \\
2 \\
3 a-b-c\end{array}$ & $\begin{array}{r}294 \\
37 \\
97\end{array}$ & $\begin{array}{r}4 \\
4 \\
12\end{array}$ & $\begin{array}{r}290 \\
33 \\
85\end{array}$ & $p<0,001$ \\
\hline
\end{tabular}

AWOD: alive without disease $=$ tumormentes túlélö, DOD: dead of disease $=$ veserák következtében elhunyt

\section{Az MMP12-expresszió immunhisztokémiai vizsgálata}

Az MMP12-expresszió vizsgálatát 492 betegnél végeztük el (1. csoport), amelyek közül 429 betegnél volt a betegség-felismeréskor szervre lokalizált (2. csoport). Metasztázis a mútét idején 63 betegnél volt jelen, míg a felismeréskor nem metasztatikus betegek közül 85 esetben volt észlelhetô progresszió a nyomonkövetés során. Összesen 148 betegnél $(30,1 \%)$ alakult ki végzetes progresszió. A férfinő arány 314:178 (63,8\% és 36,2\%), az átlagos életkor 61,52 év volt. Az átlagos tumorméret a vizsgálat végéig elhunyt betegeknél 87 mm volt, míg a túlélő betegek csoportjánál $51 \mathrm{~mm}$.

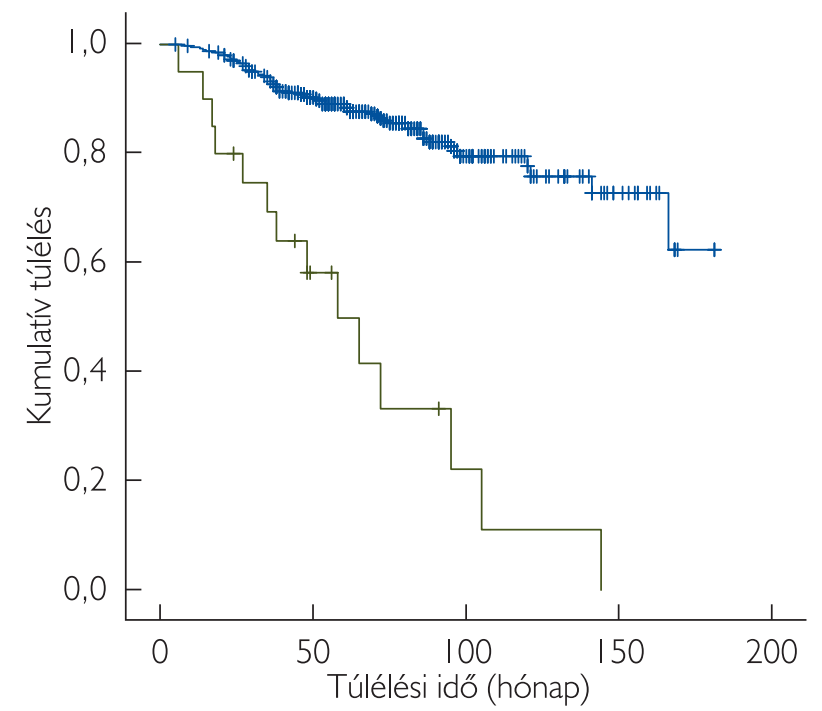

2. ÁBRA: LOG-RANK TESZT ALKALMAZÁSÁvAL VÉGZETT KAPLAN-MEIER TÚLÉLÉS-ANALízIS SAA1 NEGATív (KÉK GÖRBE) ÉS SAA1 POZITíV (ZÖLD GÖRBE) TUMORRAL RENDELKEZŐ BETEGEK ESETÉN, A TELJES BETEGANYAGON $(\mathrm{N}=429)$

Az MMP12-antitesttel megfestett metszetek értékelése során a pozitívan festődő mintákban a tumorsejtek legalább 80\%-a festődött, így a pozitívan festődő sejtek számát értékelendő paraméterként nem vettük figyelembe. A festődés mértékének osztályozása során elkülönítettünk nem festődő, gyengén festődő, közepesen festődő és erősen festődő eseteket. Az MMP12-expresszió vizsgálatát normál fötális és felnőtt veseszöveten is elvégeztük. Érdekes módon, normál vesén kizárólag a distalis tubulus sejtek mutattak erős MMP12-festődést (3. ábra A-B). A 492 konvencionális típusú veserákminta MMP12antitesttel történő immunhisztokémiai vizsgálata során 116 esetben föként gyenge és közepes, néha erős festődés volt megfigyelhető, míg 376 tumor nem mutatott MMP12-festődést (3. ábra C-F). Az immunreakció intezitását figyelembe vevő első statisztikai feldolgozás során a daganatspecifikus halálozásra nézve nem volt kimutatható lényegi különbség a gyen-

\section{TÁblÁZAT: A KLINIKOPATOLóGIAI PARAMÉTEREK ÉS AZ SAA1-EXPRESSZIÓ ÖSSZEFÜGGÉSE A DAGANATSPECIFIKUS} TÚLÉLÉSSEL COX-REGRESSZIÓS ANALÍZIS SORÁN

\section{Egyváltozós analízis}

Többváltozós analízis

\begin{tabular}{lcccc} 
Paraméterek & Relatív rizikó $(95 \% \mathrm{Cl})$ & p-érték & Relatív rizikó $(95 \% \mathrm{Cl})$ & -érték \\
Kor (év) & $1,02(1,00-1,04)$ & 0,088 & $1,01(0,99-1,03)$ & 0,234 \\
Nem (férfi/nő) & $1,12(0,73-1,71)$ & 0,578 & $1,00(0,63-1,59)$ & 0,986 \\
\hline T-stádium T1a-b & & $<0,001$ & $<, 001$ \\
\multicolumn{1}{c}{ T2 } & $4,95(2,50-9,80)$ & $<0,001$ & $4,36(2,09-9,07)$ & $<0,001$ \\
T3a-b-c & $8,74(5,36-14,25)$ & $<0,001$ & $6,19(3,50-10,93)$ & $<0,001$ \\
Grade (G1/ G2-3) & $3,84(2,49-5,94)$ & $<0,001$ & $2,33(1,39-3,91)$ & 0,001 \\
Tumorméret (cm) & $1,02(1,02-1,03)$ & $<0,001$ & $1,00(0,99-1,01)$ & 0,314 \\
SAA1 (+ / 0) & $6,61(3,70-11,83)$ & $<0,001$ & $2,11(1,14-3,92)$ & 0,017
\end{tabular}




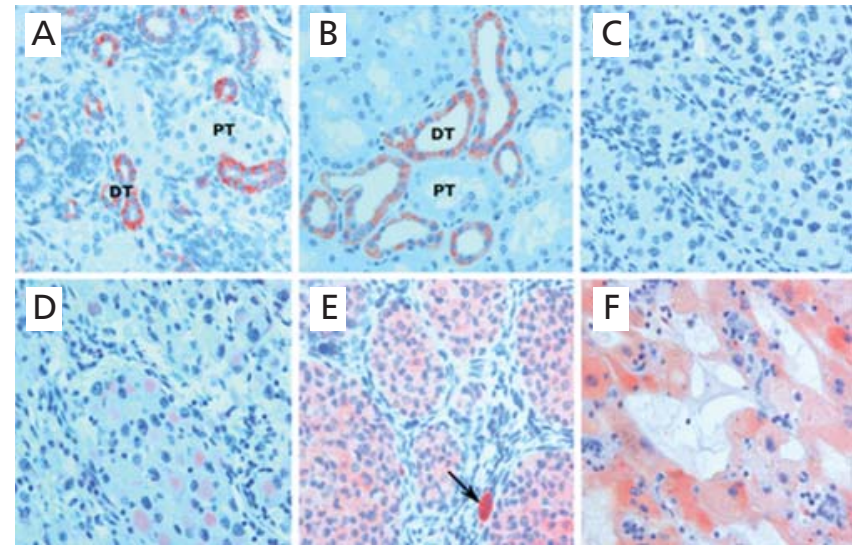

3. ÁBRA: AntI-MMP12-AntitestTel VÉGZEtT IMMUNHISZTOKÉMIA SORÁN ÉSZLELT FESTŐDÉS FÖTÁLIS (A) ÉS FELNŐTT (B) NORMÁL VESÉN, VALAMINT NEM FESTŐDŐ (C) ÉS KÜLÖNBÖZŐ INTENZITÁSSAL FESTŐDŐ (D-E-F) KONVENCIONÁLIS TíPUSÚ RCC-MINTÁK. EGY STROMÁBAN MEGFIGYELT MAKROFÁG INTENZÍV POZITIVITÁST MUTAT ( $\mathrm{E}_{\text {, }}$ NYíL). DT: DISTAALS TUBULUS, PT: PROXIMALIS TUBULUS

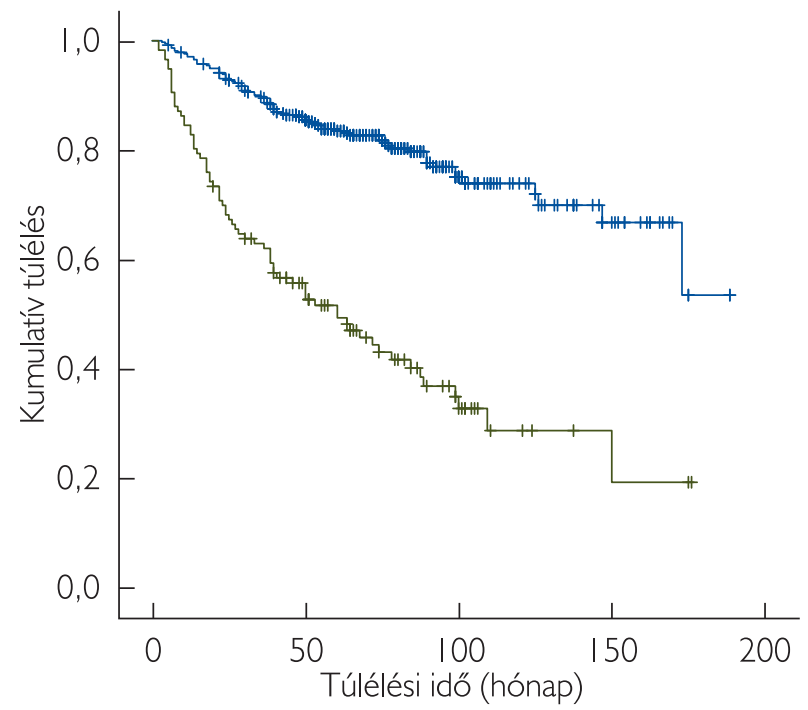

4. ÁBRA: LOG-RANK TESZT ALKALMAZÁSÁVAL VÉGZETT KAPLAN-MEIER tÚLÉlÉS-ANALízIS aZ MMP12 NEGATív (KÉK GÖRBE) ÉS MMP12 POZITíV (ZÖLD GÖRBE) TUMORRAL RENDELKEZŐ BETEGEK ESETÉN, A TELJES BETEGANYAGON

gén és a közepes mértékben festődő tumorok között. Emiatt végül úgy döntöttünk, hogy az immunhisztokémia értékelése során csupán az MMP12-expresszió szempontjából pozitív és negatív eseteket különítjük el egymástól.

\section{Az MMP12-expresszió összehasonlítása a klinikopatológiai jellemzőkkel}

Az MMP12-expresszió és a klinikopatológiai változók, mint a veserák következtében bekövetkezett halálozás, a tumorméret, a nukleáris grádus, a T-stádium, a TNM-stádium, a koagu-
3. TÁBLÁZAT: AZ MMP12-EXPRESSZIÓ ÉS A KONVENCIONÁLIS VESERÁK KLINIKOPATOLÓGIAI JELLEMZÖI KÖZÖTTI ÖSSZEFÜGGÉSEK

\begin{tabular}{|c|c|c|c|c|}
\hline \multirow{3}{*}{ Státusz } & \multirow{2}{*}{$\begin{array}{c}\text { Esetek } \\
\text { száma } 492\end{array}$} & \multicolumn{2}{|c|}{ MMP12 } & \multirow{2}{*}{ p-érték } \\
\hline & & + & - & \\
\hline & & & & \\
\hline AWOD & 344 & 46 & 298 & $<0,001$ \\
\hline DOD & 148 & 70 & 78 & \\
\hline \multicolumn{5}{|c|}{ Tumorméret } \\
\hline$<4 \mathrm{~cm}$ & 190 & 19 & 171 & $<0,001$ \\
\hline $4-7 \mathrm{~cm}$ & 171 & 43 & 128 & \\
\hline$>7 \mathrm{~cm}$ & 131 & 54 & 77 & \\
\hline \multicolumn{5}{|l|}{ Grade } \\
\hline G1 & 272 & 22 & 250 & $<0,001$ \\
\hline G2 & 140 & 44 & 96 & \\
\hline G3 & 80 & 50 & 50 & \\
\hline \multicolumn{5}{|c|}{ T-stádium } \\
\hline T1a-b & 296 & 41 & 255 & $<0,001$ \\
\hline $\mathrm{T} 2$ & 40 & 11 & 29 & \\
\hline T3a-b-c & 148 & 59 & 89 & \\
\hline T4 & 8 & 5 & 3 & \\
\hline \multicolumn{5}{|l|}{ Stage } \\
\hline$|/| \mid$ & 320 & 448 & 272 & $<0,001$ \\
\hline III/IV & 172 & 68 & 104 & \\
\hline \multicolumn{5}{|c|}{ Nekrózis } \\
\hline van & 431 & 84 & 347 & $<0,001$ \\
\hline nincs & 61 & 32 & 29 & \\
\hline \multicolumn{5}{|c|}{ Metasztázis* } \\
\hline van & 63 & 38 & 25 & $<0,001$ \\
\hline nincs & 429 & 78 & 351 & \\
\hline
\end{tabular}

*a mútét idején, AWOD: alive without disease = tumormentes túlélő, DOD: dead of disease $=$ veserák következtében elhunyt

lációs nekrózis jelenléte és a mútét idején fennálló metasztázis közötti viszony statisztikai elemzése során mindegyik paraméter tekintetében szignifikáns összefüggés volt kimutatható $(p<0,001)$ (3. táblázat)

\section{Az MMP12-expresszió és a túlélési adatok közötti összefüggés}

A daganatspecifikus túlélést külön értékeltük az összes beteg (1-es csoport) és a mútét idején metasztázissal nem bíró betegek (2-es csoport) esetén. A medián túlélési idő az MMP12 pozitív betegeknél az 1-es csoportban 58 hónap volt (4. ábra), míg a 2-es csoportban 105 hónap (5. ábra). A log-rank teszt alkalmazásával végzett Kaplan-Meier túlélés-analízis mindkét csoportban az MMP12-antitesttel pozitívan festődő tumorok esetén szignifikánsan rövidebb túlélést igazolt $(p<0,001)$. Egyváltozós analízis során az ismert klinikai változók (a tumorméret, a nukleáris grádus, a T-stádium, a TNMstádium, a koagulációs nekrózis jelenléte és a mútét idején fennálló metasztázis) és az MMP12-expresszió szignifikáns 


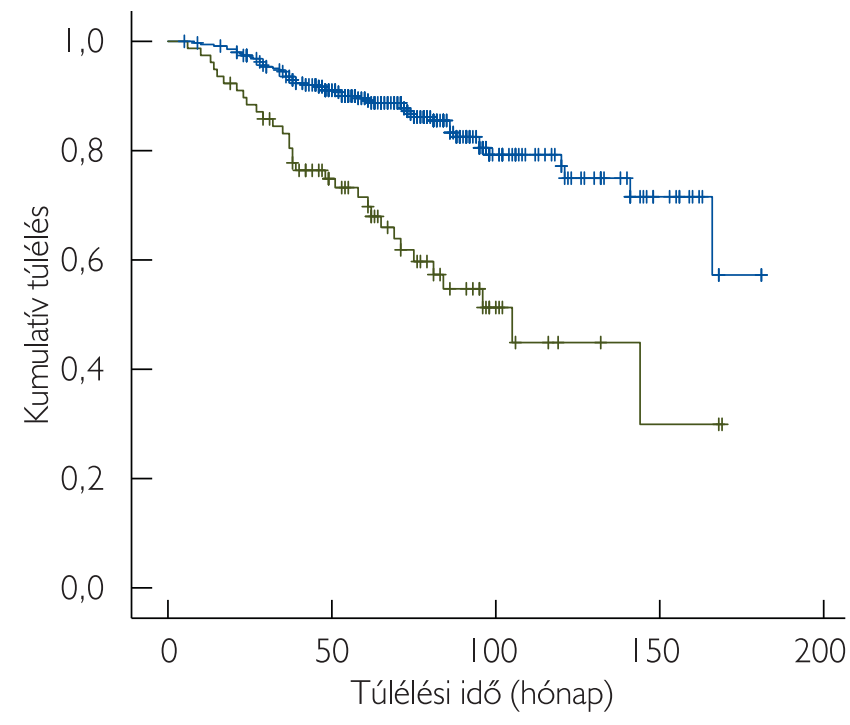

5. ÁBRA: LOG-RANK TESZT ALKALMAZÁSÁVAL VÉGZETT KAPLAN-MEIER TÚLÉLÉS-ANALÍZIS AZ MMP12 NEGATív (KÉK GÖRBE) ÉS MMP12 POZITíV (ZÖLD GÖRBE), FELISMERÉSKOR SZERVRE LOKALIZÁLT TUMORRAL RENDELKEZŐ BETEGEKNÉL

összefüggést mutattak a túléléssel. Többváltozós analízis során (4. táblázat) a 1-es csoportban a T1-T2-stádium, a nukleáris grádus, a TNM-stádium, a nekrózis jelenléte, a mútét idején meglévő metasztázis és a tumor mérete bizonyult a daganatspecifikus túlélés előrejelzése szempontjából szignifi-

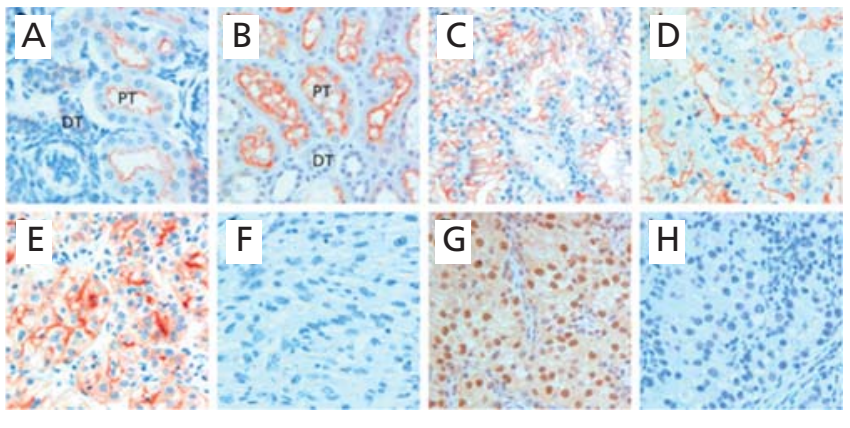

6. ÁBRA: ANTI-TMEM27-ANTITESTTEL VÉGZETt IMMUNHISZTOKÉMIA SORÁN MIND A FÖTÁLIS (A) ÉS FELNŐTT (B) NORMÁL VESÉBEN KIZÁRÓLAG A PROXIMÁLIS TUBULUSOKBAN (PT) TALÁLTUNK POZITIVITÁST. A KONVENCIONÁLIS VESERÁKOKBAN GYENGE (C), KÖZEPES (D) VAGY INTENZÍV (E) FESTŐdÉST ÉSZLELTÜNK. SZÁMOS ESETBEN EGYETLEN TUMORSEJT SEM VOLt POZITÍV (F). HNF1A-ANTITESTTEL MIND DIFFÚZ POZITÍV (G) VAGY NEGATÍV (H) FESTŐdÉST ÉSZLELTÜNK. DT: DISZTALLS TUBULUS, PT: PROXIMALLS TUBULUS

káns negatív paraméternek, amely az MMP12-expresszióról nem mondható el. Azonban a 2-es csoportba sorolt, a mútét idején nem metasztatikus eseteket vizsgálva az MMP12expresszió független prognosztikai faktornak bizonyult, amely alkalmas posztoperatív relapszus elörejelzésére $(p=0,048)$.

4. tÁBlÁZAT: A KLINIKOPATOlóGIAI PARAMÉTEREK ÉS AZ MMP12-eXPRESSZIó ÖSSZEFÜGGÉSE A DAGANATSPECIFIKUS TÚLÉLÉSSEL COX-REGRESSZIÓS ANALÍZIS SORÁN

\begin{tabular}{|c|c|c|c|c|}
\hline Többváltozós analízis & \multicolumn{2}{|c|}{ Összes beteg (492) } & \multicolumn{2}{|c|}{ Metasztázis nélküli betegek* (429) } \\
\hline Paraméterek & Relatív rizikó $(95 \% \mathrm{Cl})$ & p-érték & Relatív rizikó $(95 \% \mathrm{Cl})$ & p-érték \\
\hline Kor (év) & $1,008(0,991-1,024)$ & 0,367 & $1,007(0,986-1,028)$ & 0,522 \\
\hline Nem (férfi/ nő) & $0,958(0,667-1,377)$ & 0,819 & $0,927(0,591-1,454)$ & 0,743 \\
\hline T-stádium T1a-b & & 0,01 & & $<0,001$ \\
\hline T2 & $2,815(1,477-5,367)$ & 0,02 & $4,040(1,974-8,268)$ & $<0,001$ \\
\hline T3a-b-c & $1,636(0,819-3,270)$ & 0,164 & $6,040(3,540-10,304)$ & $<0,001$ \\
\hline T4 & $2,570(0,977-6,763)$ & 0,056 & & \\
\hline Grade & & & & \\
\hline (G1/G2-3) & $2,006(1,257-3,200)$ & 0,003 & $2,180(1,307-3,638)$ & 0,003 \\
\hline Stádium & & & & \\
\hline (I-II/III-IV) & $3,492(1,638-7,444)$ & 0,001 & $2,635(0,345-20,131)$ & 0,350 \\
\hline Nekrózis & & & & \\
\hline (van/nincs) & $1,833(1,239-2,711)$ & 0,002 & $1,550(0,859-2,799)$ & 0,146 \\
\hline Metasztázis* & & & & \\
\hline (van/nincs) & $5,805(3,814-8,837)$ & $<0,001$ & & \\
\hline Tumorméret (cm) & $1,006(1,001-1,012)$ & 0,028 & $1,002(0,993-1,012)$ & 0,631 \\
\hline MMP12 $(0 /+)$ & $1,260(0,874-1,816)$ & 0,216 & $1,612(1,004-2,589)$ & 0,048 \\
\hline
\end{tabular}

$\mathrm{Cl}$ : konfidencia intervallum, *a mútét idején 
5. TÁBLÁZAT: A TMEM27-EXPRESSZIÓ ÉS A KONVENCIONÁLIS VESERÁK KLINIKOPATOLÓGIAI JELLEMZÖI KÖZÖTTI ÖSSZEFÜGGÉSEK

\begin{tabular}{|c|c|c|c|c|}
\hline \multirow{2}{*}{\multicolumn{2}{|c|}{$\begin{array}{c}\text { Esetek } \\
\text { száma (486) }\end{array}$}} & \multicolumn{2}{|c|}{ TMEM27 } & \multirow{2}{*}{ p-érték } \\
\hline & & + & - & \\
\hline Kor & & & & 0,567 \\
\hline átlag & & 60,8 & 61,5 & \\
\hline SE & & 1,02 & 0,59 & \\
\hline Nem & & & & 0,877 \\
\hline férfi & 313 & 230 & 83 & \\
\hline nő & 173 & 126 & 47 & \\
\hline Státusz & & & & $<0,001$ \\
\hline AWOD & 339 & 293 & 46 & \\
\hline DOD & 147 & 63 & 84 & \\
\hline Tumorméret & & & & $<0,001$ \\
\hline$<4 \mathrm{~cm}$ & 181 & 156 & 25 & \\
\hline $4-7 \mathrm{~cm}$ & 175 & 131 & 44 & \\
\hline$>7 \mathrm{~cm}$ & 130 & 69 & 61 & \\
\hline Grade & & & & $<0,001$ \\
\hline G1 & 265 & 239 & 26 & \\
\hline G2 & 140 & 95 & 45 & \\
\hline G3 & 81 & 22 & 59 & \\
\hline T-stádium & & & & $<0,001$ \\
\hline T1a-b & 293 & 252 & 41 & \\
\hline T2 & 40 & 28 & 12 & \\
\hline T3a-b-c & 145 & 75 & 70 & \\
\hline T4 & 8 & 1 & 7 & \\
\hline Stádium & & & & $<0,001$ \\
\hline I/II & 316 & 270 & 46 & \\
\hline III/IV & 170 & 86 & 84 & \\
\hline Metasztázis* & & & & $<0,001$ \\
\hline van & 64 & 22 & 42 & \\
\hline nincs & 422 & 334 & 88 & \\
\hline
\end{tabular}

*a mútét idején, AWOD: alive without disease = tumormentes túlélő, DOD: dead of disease = veserák következtében elhunyt

\section{TMEM27-expresszió immunhisztokémiai vizsgálata}

TMEM27-expresszió vizsgálatára 486 beteg (1. csoport) került beválasztásra retrospektív módon. Az 1. csoportból 422 beteg (2. csoport) a diagnózis felállítása idején nem rendelkezett metasztázissal. Az 1. csoportba sorolt betegek 13 százalékánál volt észlelhető metasztázis a mútét időpontjában. A 2. csoportban a betegek 17 százalékánál jelentkezett progresszió a nyomonkövetés során. Az összes beteg 29 százalékánál alakult ki metasztatikus állapot. Az átlagos nyomonkövetési idő 65,5×37,1 hónap volt. A férfi:nő arány 313:173 (64,4\% és 35,6\%), az átlagos életkor 61,3 év volt. Az átlagos tumorméret a vizsgálat végéig elhunyt betegek esetén $86 \mathrm{~mm}$ volt, míg a túlélő betegek csoportjánál csak 52 mm.

Immunhisztokémiai vizsgálatra azért választottuk ki a TMEM27-gént, mivel ez kizárólagosan a proximális tubulusban fejeződik ki, amely a konvencionális veserák kiindulási helyének tekinthető. Fötális vesében immunhisztokémia során a TMEM27 halvány, membránhoz kötött expressziót mutatott a proximális tubulusok luminális felszínén (6. ábra A). Felnőtt vesében a TMEM27 szintén proximális tubulusok luminális felszínén fejeződött ki, azonban a festődés jelentősen intenzívebb volt (6. ábra B). A vizsgálat során 486 beteg paraffin blokkjaiból esetenként kiemelt 1-4 szövethenger felhasználásával készített TMA-t festettük meg TMEM27-antitesttel. Változatos intenzitású, kizárólag membránhoz kötött festődést észleltünk 356 tumornál, míg 130 eset TMEM27-negatívnak bizonyult (6. ábra C-F).

Ugyanabból a tumorból nyert, különböző grádusú, illetve megjelenésű területeket reprezentáló többes minták esetén, amennyiben pozitív és negatív festődés is előfordult, az eredményt negatívnak tekintettük.

Annak érdekében, hogy alátámasszuk a TMEM27-festődés specificitását, a vizsgálatot egyéb típusú vesetumormintákon is elvégeztük. A vizsgált 54 papilláris veserák mintából 9 esetben a minta kis területein gyenge pozitív festődés volt észlelhető a sejtek felszínén, főként a jobban differenciálódott, a proximális tubulus sejtekre hasonlító eozinofil sejtekben. A vizsgált 21 kromofób veserák, 33 vese oncocytoma, hét mucinózus tubuláris és orsósejtes karcinóma (MTSCC), hat metanefrikus adenoma és kilenc Wilms-tumor minta egyike sem mutatott pozitív festődést TMEM27-antitesttel.

A rendelkezésre álló experimentális irodalmai adatok arra utalnak, hogy a HNF1A transzkripciós aktivátor szabályozza a TMEM27 expresszióját (12). Ennek ismeretében anyagunkon megvizsgáltuk HNF1A kifejeződését. Eredményeink alapján normál veseszövetben mind a két gén a proximális tubulusokra lokalizálódik, azonban konvencionális veserákokban nem találtunk összefüggést a két gén expressziója között (6. ábra $\mathrm{G}-H$ ).

\section{A TMEM27-expresszió összehasonlítása a klinikopatológiai jellemzőkkel}

A TMEM27-fehérje expresszió és a klinikopatológiai jellemzők viszonyát az 5. táblázat foglalja össze. A TMEM27-expresszió szignifikáns összefüggést mutatott a túléléssel, a tumormérettel, a grádussal, a T-stádiummal, a TNM-stádiummal és a mútét időpontjában a metasztázis jelenlétével.

\section{Az TMEM27-expresszió és a túlélési adatok közötti összefüggés}

Az átlagos nyomonkövetési idő 65,5×37,1 hónap volt. A logrank teszt alkalmazásával végzett Kaplan-Meier túlélés-analízis a TMEM27 negatív tumorral rendelkező betegek esetén rossz daganatspecifikus túlélést mutatott mindkét betegcsoportban (7. és 8. ábra). A TMEM27 kifejeződésének hiánya az 1-es csoportban 39 hónap $(23,6-54,4,95 \%$ Cl), a 2-es csoportban 58 hónap (53-108, 95\% Cl) medián túlélési idővel járt együtt. Egyváltozós analízis során az 1-es és 2-es csoportba tartozó TMEM27 negatív tumorral rendelkező betegeknél a daganatspecifikus halálozás rizikója szignifikánsabb magasabb volt a 


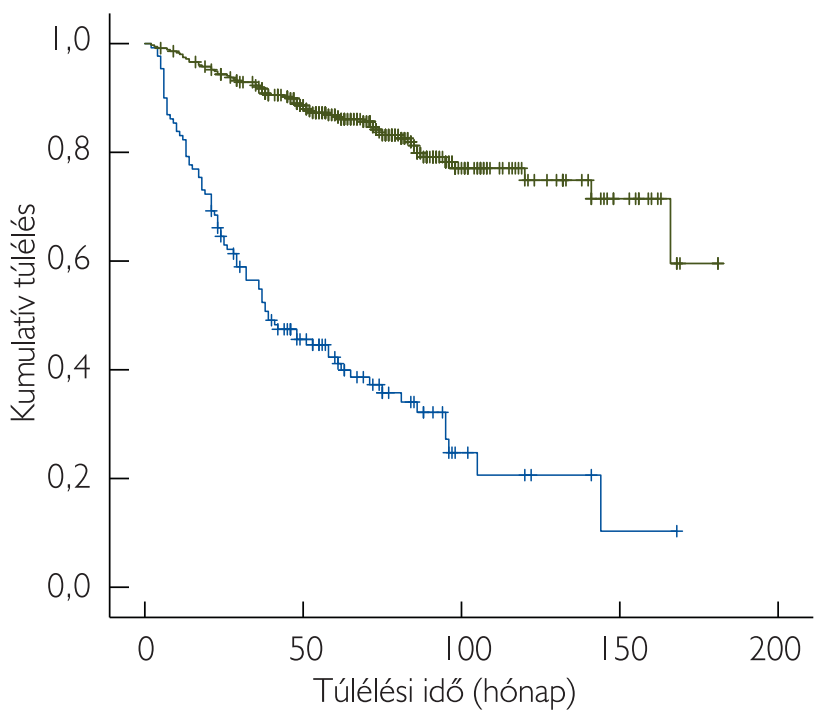

7. ÁBRA: Log-RANK TESZT ALKALMAZÁSÁVAL VÉGZETT KAPLAN-MEIER TÚLÉLÉS-ANALízIS A TMEM27 negATíV (KÉK GÖRBE) És TMEM27 POZITÍV (ZÖLD GÖRBE) TUMORRAL RENDELKEZŐ BETEGEK ESETÉN, A TELJES BETEGANYAGON

TMEM27 pozitív esetekhez képest. A TMEM27-festődés független prognosztikai értékének meghatározása érdekében többváltozós analízist végeztünk az ismert klinikopatológiai prognosztikai változókat figyelembe véve (6. táblázat).

Az 1-es csoportban a T-stádium, a tumorméret, a metasztázis felismeréskori jelenléte és a TMEM27-expresszió bizonyult statisztikailag szignifikánsnak (RR: -2,76; 95\% Cl-1,91-3,99;

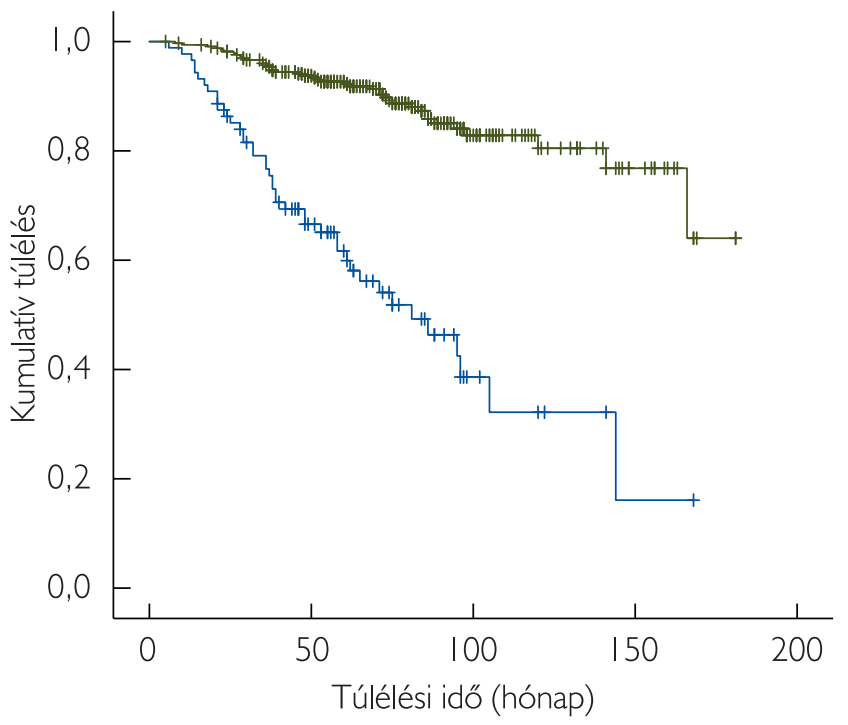

8. ÁBRA: LOG-RANK TESZT ALKALMAZÁSÁVAL VÉGZETT KAPLAN-MEIER TÚLÉLÉS-ANALíZIS A TMEM27 negatív (KÉK GÖRBE) ÉS TMEM27 POZITÍV (ZÖLD GÖRBE), FELISMERÉSKOR SZERVRE LOKALIZÁLT TUMORRAL RENDELKEZŐ BETEGEKNÉL

$p<0,001)$. A 2-es csoportba sorolt, a mútét idején nem metasztatikus eseteknél csak a T-stádium és a TMEM27expresszió volt szignifikáns (RR: $-2,95 ; 95 \%$ Cl: $-1,81-4,80$; $\mathrm{p}<0,001$ ). Tehát a TMEM27-expresszió hiánya független negatív biológiai prognosztikai faktornak tekinthető, amely kedvezőtlen daganatspecifikus túléléssel jár együtt konvencionális RCC esetén.

\section{TÁBLÁZAT: KLINIKOPATOLÓGIAI PARAMÉTEREK ÉS A TMEM27-EXPRESSZIÓ ÖSSZEFÜGGÉSE A DAGANATSPECIFIKUS} TÚLÉLÉSSEL COX-REGRESSZIÓS ANALÍZIS SZERINT

\begin{tabular}{|c|c|c|c|c|}
\hline Többváltozós analízis & \multicolumn{2}{|c|}{ Összes beteg (486) } & \multicolumn{2}{|c|}{ Metasztázis nélküli betegek* (422) } \\
\hline Paraméterek & Relatív rizikó $(95 \% \mathrm{Cl})$ & p-érték & Relatív rizikó $(95 \% \mathrm{Cl})$ & p-érték \\
\hline Kor (év) & $1,01(0,99-1,03)$ & 0,088 & $1,02(0,99-1,04)$ & 0,064 \\
\hline Nem (ffi/nő) & $0,94(0,65-1,36)$ & 0,768 & $0,83(0,52-1,33)$ & 0,451 \\
\hline T1a-b & & 0,025 & & $<0,001$ \\
\hline T2 & $2,08(1,06-4,07)$ & 0,032 & $4,16(2,03-8,52)$ & $<0,001$ \\
\hline T3a-b-c & $0,75(0,36-1,57)$ & 0,455 & $5,15(2,95-8,97)$ & $<0,001$ \\
\hline T4 & $1,08(0,39-2,96)$ & 0,873 & & \\
\hline Grade & & & & \\
\hline (G1/G2-3) & $1,55(0,94-2,54)$ & 0,081 & $1,72(0,99-2,99)$ & 0,051 \\
\hline Stádium & & & & \\
\hline$(\mathrm{I}-\mathrm{II} / \mathrm{III}-\mathrm{IV})$ & $5,18(2,48-10,82)$ & $<0,001$ & $2,35(0,31-17,87)$ & 0,407 \\
\hline Metasztázis* & & & & \\
\hline (van/nincs) & $5,97(3,92-9,09)$ & $<0,001$ & & \\
\hline Tumorméret (cm) & $1,00(1,00-1,01)$ & 0,003 & $1,00(0,99-1,01)$ & 0,255 \\
\hline TMEM27 (+ / 0) & $2,76(1,91-3,99)$ & $<0,001$ & $2,95(1,81-4,80)$ & $<0,001$ \\
\hline
\end{tabular}

$\mathrm{Cl}$ : konfidencia intervallum, *a mútét idején 


\section{Megbeszélés}

Az utóbbi évtizedekben a képalkotó eljárások széles körû használata a veserák alacsonyabb stádiumban történő felismeréséhez vezetett. Az incidentálisan felismert T1a, T1b és T2 tumorok száma a legtöbb urológiai centrum mútéti statisztikájában emelkedő tendenciát mutat. Bár ezek a tumorok alacsonyabb gyakorisággal progrediálnak, mint a magasabb stádiumú (T3, T4) tumorok, azonban körülbelül 15-20 százalékuknál a nyomonkövetés során metasztázis jelentkezik (13, 14). Ezen magas rizikójú betegcsoport csoport felismerésére kevés marker ismert. Vizsgálataink során három, a daganat progresszióját elősegítő, illetve jelző markert azonosítottunk. Igazoltuk, hogy az SAA1 akutfázis-protein kifejeződése a tumorsejtek citoplazmájában szignifikánsan társul azon daganatok posztoperatív progressziójával, amelyek a felismeréskor még a vesére lokalizálódtak. Adataink megerősítik a konvencionális vese tumorok mikrokörnyezetében lezajló gyulladásos folyamatok szerepét a tumor progresszióban (6).

Továbbá igazoltuk, hogy az MMP12 citoplazmatikus expressziója konvencionális veserákban összefüggésben áll a posztoperatív metasztázis képződéssel és a rövidebb daganatspecifikus túléléssel. Ez annak tükrében érthető, hogy nemcsak a gyulladásos folyamatok felerősítése, hanem a tumor stroma leépítése, lebontása is szükséges a sejtek szabad mozgásához és így a metasztázisok kialakulásához $(7,8)$. Ebben a folyamatban az MMP12-nek jelentős szerepe van.

Az invázióhoz és sejtmozgáshoz szükséges a normális epitheliális forma átmeneti feladása, azaz az epithel-mesenchymatranzíció (EMT). Ennek során a sejtek átalakítják belső szerkezetüket. Pl. a normális epithelsejtekre jellemző keratin 8 és 18 mellett megjelenik a keratin 7 és 19 expressziója, vagy más, a sejtek plaszticitását megváltoztató gének kifejeződése (9). Mivel a TMEM27 struktúrfehérje a proximális tubulus polarizált epitheljének a funkciójához elengedhetetlen, ennek elvesztése az EMT-n átesett magas malignitású tumorokban érthető. Bár nem függ össze közvetlenül a daganatprogresszióval, a TMEM27-expresszió megbízható marker a posztoperatív daganatspecifikus túlélés előrejelzésére felismeréskor klinikailag szervre lokalizált konvencionális veserákban szenvedő betegeknél.

\section{Következtetések}

Az SAA1-, MMP12- és TMEM27-gének kitűnő biomarkerként használhatók, amelyek alkalmasak a posztoperatív daganatspecifikus túlélés előrejelzésére felismeréskor klinikailag szervre lokalizált konvencionális veserákban szenvedő betegeknél. Az immunhisztokémiai vizsgálat megbízható és alacsony költségú módszer. A további munka során igazolt markerekkal a jövőben használhatóak lesznek a progresszió elörejelzésre önmagukban, vagy egymással, illetve más biomarkerekkel és klinikai változókkal kombinálva egy integrált prognosztikai rendszer részeként. Az így létrehozott új integrált prognosztikai rendszer prediktív képességének értékeléséhez természetesen belső és külső validálás is szükséges. Az új prognosztikai rendszerrel azonosított magas rizikójú esetek fokozott intenzitású ellenőrzése biztosíthatná a relapszus korai felismerését, ezáltal lehetővé téve a további sebészi kezelés (lokális recidíva mútéti eltávolítása, metasztázis mütéti eltávolítása) elvégzését és a target terápia elindítását még a beteg általános állapotának leromlása előtt. A biomarkerek kifejeződésére alapozott, rizikóhoz adaptált nyomonkövetés feltehetően fokozná a másodlagos kezelés hatékonyságát, ezáltal túlélési előnyt biztosítva az érintett betegeknek.

\section{Irodalom}

1. Ferlay J, Steliarova-Foucher E, Lortet-Tieulent J, Rosso S, Coebergh $J W$, et al. Cancer incidence and mortality patterns in Europe: estimates for 40 countries in 2012. Eur J Cancer 2013; 49(6): 13741403. https://doi.org/10.1016/j.ejca.2012.12.027

2. Frank I, Blute ML, Cheville JC, Lohse CM, Weaver AL, Zincke H. An outcome prediction model for patients with clear cell renal cell carcinoma treated with radical nephrectomy based on tumor stage, size, grade and necrosis: the SSIGN score. J Urol 2002; 168(6): 2395-2400. https://doi.org/10.1016/50022-5347(05)64153-5

3. Kim HL, Seligson $\mathrm{D}$, Liu $\mathrm{X}$, Janzen $\mathrm{N}$, Bui MH, et al. Using tumor markers to predict the survival of patients with metastatic renal cell carcinoma. J Urol 2005; 173(5): 1496-1501. https://doi.org/ 10.1097/01.ju.0000154351.37249.fo

4. Parker AS, Leibovich $B C$, Lohse $C M$, Sheinin $Y$, Kuntz SM, et al. Development and Evolution of BioScore: A biomarker panel to enhance of prognostic algorithms for clear cell renal cell carcinoma. Cancer 2009; 115(10): 2092- 103. https://doi.org/10.1002/cncr.24263

5. Joseph RW, Kapur P, Serie DJ, Eckel-Passow JE, Parasramka M, et al. A Loss of BAP1 protein expression is an independent marker of poor prognosis in patients with low-risk clear cell renal cell carcinoma. Cancer 2014; 120(7): 1059-1067. https://doi.org/10.1002/cncr.28521

6. Balkwill F, Mantovani A. Inflammation and cancer: back to Virchow? Lancet 2001; 357: 539-545. https://doi.org/10.1016/S01406736(00)04046-0
7. Kessenbrock K, Plaks V and Werb Z. Matrix metalloproteinase: regulators of the tumor microenvironment. Cell 2010; 141: 52-67. https://doi.org/10.1016/j.cell.2010.03.015

8. Nguyen-Ngoc KV, Cheung KJ, Brenot A, Shamir ER, Gray RS, et al. ECM microenvironment regulates collective migration and nodal dissemination in normal and malignant mammary epithelium. Proc Natl Acad Sci U.S.A. 2012; 109: E2595-E2604. https://oi.org/10.1073/pnas. 1212834109

9. Conant JL, Peng Z, Evans MF, et al. Sarcomatoid renal cell carcinoma is an example of epithelial-mesenchymal transition. J Clin Pathol 2011; 64(12): 1088-1092. https://doi.org/10.1136/jclinpath-2011-200216

10. Kovacs G, et al. The Heidelberg classification of renal cell tumours. J Pathol 1997; 183: 131-133. https://doi.org/10.1002/(SICI) 1096-9896 (199710) 183:2<131::AID-PATH931>3.0.CO;2-G

11. Sobin LH, Gospodarowicz MK, Wittekind C, (Eds). TNM Classification of Malignant Tumours. 7th Edition, Wiley-Blackwell; 2009.

12. Fukui K, Yang Q, Cao Y, Takahashi N, Hatakeyama H, et al. The HNF1 target collectrin controls insulin exocytosis by SNARE complex formation. Cell Metab 2005; 2(6): 373-384. https://doi.org/10.1016/ j.cmet.2005.11.003

13. Chow WH, et al. Epidemiology and risk factors for kidney cancer. Nat Rev Urol 2010; 7: 245-257. https://doi.org/ 10.1038/nrurol.2010.46

14. Levi F, Ferlay J, Galeone C, Lucchini F, Negri E, et al. The changing pattern of kidney cancer incidence and mortality in Europe. BJU Int 2008; 101: 949-958. https://doi.org/10.1111/j.1464-410X.2008.07451.x 